\title{
Effects of Allium tuncelianum on hyperglycemia and oxidative stress in the kidney and liver tissues in rats with diabetes mellitus induced by streptozotocin
}

\author{
Gözde ATILA ${ }^{1}$, Ali BİLGILİ ${ }^{2}$ Hamit USLU ${ }^{3}$, Dinçer ERDAĞ $\breve{4}^{4}$, Oktay ÖZKAN $^{5}$
}

\begin{abstract}
${ }^{1}$ Kafkas University, Faculty of Veterinary Medicine, Department of Physiology, Kars; ${ }^{2}$ Ankara University, Faculty of Veterinary Medicine, Department of Pharmacology and Toxicology, Ankara; ${ }^{3}$ Kafkas University, Ataturk Health Vocational School, Department of Health Care Services, Kars; ${ }^{4}$ Kafkas University, Ataturk Health Vocational School, Department of Medical Services and Techniques, Kars; ${ }^{5}$ Ömer Halisdemir University, Faculty of Medicine, Department of Medical Pharmacology, Niğde, Turkey.
\end{abstract}

\begin{abstract}
Summary: In this study, it was aimed to investigate the effects of Allium tuncelianum extract on hyperglycemia and oxidative stress in the kidney and liver tissues in rats with diabetes mellitus induced by streptozotocin. The rats were randomly divided into 4 groups with 10 animals in each group: Control group (C) was intraperitoneally (i.p.) treated with physiological saline solution, diabetic control (DC) group i.p. with a single dose of $50 \mathrm{mg} / \mathrm{kg}$ streptozotocin (STZ), diabetic + insulin (D+I) group i.p. with a single dose of $50 \mathrm{mg} / \mathrm{kg} \mathrm{STZ}$ and subcutaneously (s.c.) with $2 \mathrm{IU}$ insulin for 28 days (Levemir Flexpen), diabetic + Allium tuncelianum extract (D+AT) group i.p. with a single dose of $50 \mathrm{mg} / \mathrm{kg} \mathrm{STZ}$ and orally with $250 \mathrm{mg} / \mathrm{kg}$ Allium tuncelianum extract for 28 days. The serum glycated hemoglobin (HbA1c), insulin levels and the kidney and liver thiobarbituric acid reactive substances (TBARS), superoxide dismutase (SOD), and catalase (CAT) activities were determined by using ELISA kits. Increased blood glucose levels ( $<<0.001$ ), increased TBARS levels ( $<<0.001, \mathrm{p}<0.01$ respectively), and decreased SOD and CAT activities $(\mathrm{p}<0.001)$ in the kidney and liver tissue homogenates were determined in diabetic control group compared to control group. Allium tuncelianum extract had potent antioxidant activities in the diabetic rats, and demonstrated improvement effects by increasing insulin levels, decreasing glycated hemoglobin levels, and attenuating oxidative stress in the diabetic rats. This study suggests that Allium tuncelianum extract may have therapeutic potential for patients with diabetes.

Keywords: Allium tuncelianum, antioxidant, diabetes, oxidative stress, rat.
\end{abstract}

\section{Streptozotosin ile diyabetes mellitus oluşturulan sıçanlarda Allium tuncelianum'un hiperglisemi ve böbrek ve karaciğer dokularında oksidatif stres üzerine etkileri}

Özet: Bu çalışmada streptozotosin ile diyabetes mellitus oluşturulan sıçanlarda Allium tuncelianum ekstraktının hiperglisemi ve böbrek ve karaciğer dokularında oksidatif stres üzerine etkilerini araştırmak amaçlandı. Sıçanlar her bir grupta 10 hayvan olacak şekilde rastgele 4 gruba ayrıldı: Kontrol grubuna (C) periton içi (i.p.) fizyolojik tuzlu su, diyabetli kontrol (DC) grubuna i.p. tek doz $50 \mathrm{mg} / \mathrm{kg}$ streptozotosin (STZ), diyabet + insülin (D+I) grubuna i.p. tek doz $50 \mathrm{mg} / \mathrm{kg} \mathrm{STZ} \mathrm{ve} 28$ gün süre ile deri altı (s.c.) 2 IU insülin (Levemir Flexpen), diyabet + Allium tuncelianum ekstrakt (D+AT) grubuna i.p. tek doz $50 \mathrm{mg} / \mathrm{kg} \mathrm{STZ}$ ve 28 gün süre ile ağızdan $250 \mathrm{mg} / \mathrm{kg}$ Allium tuncelianum ekstraktı ugulandı. Serum glikozile hemoglobin (HbA1c), insülin düzeyleri ve böbrek ve karaciğer tiyobarbitürik asit reaktif maddeler (TBARS), süperoksit dismutaz (SOD) ve katalaz (CAT) aktiviteleri ELISA kitleri ile belirlendi. Kontrol grubuna göre diyabetli kontrol grubunda yüksek kan glikoz düzeyleri $(\mathrm{p}<0.001)$, böbrek ve karaciğer homojenatlarında TBARS düzeylerinde $\operatorname{artma}(\mathrm{p}<0.001, \mathrm{p}<0.01$, sırasiyla) ve SOD ve CAT aktivitelerinde azalma $(\mathrm{p}<0.001)$ belirlendi. Allium tuncelianum ekstraktı diyabetli sıçanlarda güçlü antioksidan aktivitelere sahipti ve diyabetli sıçanlarda insülin düzeylerini artırarak, glikozile hemoglobin düzeylerini azaltarak ve oksidatif stresi hafifleterek iyileştirici etkiler gösterdi. Bu çalışma Allium tuncelianum ekstraktının diyabetli hastalar için terapötik potansiyele sahip olabileceğini göstermektedir.

Anahtar sözcükler: Allium tuncelianum, antioksidan, diyabet, oksidatif stres, sıçan.

\section{Introduction}

Diabetes mellitus is a common metabolic endocrine disorder (11). Insulin-dependent diabetes mellitus is characterized by autoimmune destruction of pancreatic $\beta$ cells, and severe insulin deficiency due to loss of insulin- producing $\beta$-islet cells (39), resulting in hyperglycemia (18). It causes vascular complications such as nephropathy, neuropathy, retinopathy and peripheral vascular disease. These complications are related to the advanced glycation end products, oxidative stress, and 
inflammation (11). Pancreatic islet $\beta$-cell destruction and apoptosis, and decreased insulin secretion could be associated with oxidative stress (32). Oxidative stress in type-1 diabetes mellitus develops due to hyperglycemia, the accumulation of advanced glycosylation end products, glucose oxidation (41), and the oxidation of protein, DNA and lipids $(12,26)$. In diabetic conditions, increase of reactive oxygen species (ROS) produced by NADPH oxidase $(13,31)$ for example superoxide anion (30), hydrogen peroxide, and nitric oxide (10) and decrease of antioxidant defenses for example superoxide dismutase and catalase activities (30) are reported. Moreover, it is shown that oxidative stress in diabetic rats causes increased mitogen-activated protein kinases, increase of inflammation (increased nuclear factor-kappa B activation, tumor necrosis factor- $\alpha$ and interleukin- 6 expression), and fibrosis (21).

Medicinal herbs with hypoglycemic activity have been recently investigated as adjunctive treatments for diabetes mellitus. One of the most effective plants for lowering blood glucose levels is Allium sativum $(7,28)$.

Garlic is a member of the Liliaceae family and has bioactive compounds (8). It has been used for centuries as traditional medicine to treat several diseases (35) and consumed as food. Garlic has been suggested to have antidiabetic and antioxidant (38), anti-inflammatory (14), antifungal and antibacterial (23), and anti-atherosclerotic activities (42).

Allium tuncelianum (A. tuncelianum) is an endemic garlic species that naturally grow in a limited area between the regions of Sivas and Erzurum, especially in the Ovacik district within the plots of the Munzur Mountains. A. tuncelianum comprises bioactive compounds such as organosulfur compounds allyl methyl sulfide, diallyl disulfide, and diallyl trisulfide, phenolic substances, various fatty acids such as oleic and linoleic acids and vitamins and minerals (37). According to the author's knowledge, there have been no studies on the hypoglycemic and anti-oxidant activities of $A$. tuncelianum in diabetic rats. Therefore, the aim of this study was to investigate the effects of A. tuncelianum extract on hyperglycemia and oxidative stress in streptozotocin-induced diabetic rats.

\section{Materials and Methods}

Chemicals: Streptozotocin was purchased from the Sigma Chemical Company in China. The other reagents used in this study were obtained from various companies (Sigma, Riedel-de Haen, Fluka Companies, all in Germany).

A. tuncelianum extraction process: A. tuncelianum bulbs were obtained from Ovacık district of Tunceli, Turkey. The A. tuncelianum extraction process was performed according to the method of Ozkan et al. (27).
The bulbs were dried in a dark room. A. tuncelianum bulbs of $1000 \mathrm{~g}$ were finely minced, kept in $5000 \mathrm{ml}$ absolute ethyl alcohol at room temperature in a dark condition for $20 \mathrm{~h}$, and mingled with a period of five hours. Then, this mixture was concentrated by evaporating ethyl alcohol. The final product as A. tuncelianum extract was stored at $-20^{\circ} \mathrm{C}$.

Animals: In this study, 40 female Sprague-Dawley rats, 2 months old, weighing $200 \pm 20 \mathrm{~g}$, were supplied by the Laboratory Animal Research Center at Firat University, Elazığ, Turkey. The rats were housed in standard conditions $\left(23 \pm 1{ }^{\circ} \mathrm{C}, 12 \mathrm{~h}\right.$ light $/ 12 \mathrm{~h}$ darkness $)$. This study was approved by the Local Animal Care Ethics Committee at Kafkas University, Kars, Turkey, and was in compliance with the International Guidelines for Care and Use of Laboratory Animals (2006/063, 21.04.2016). The rats were randomly divided into 4 groups with 10 animals in each group: Control group (C) was intraperitoneally (i.p.) treated with physiological saline solution; Diabetic control (DC) group was i.p. treated with a single dose of $50 \mathrm{mg} / \mathrm{kg}$ Streptozotocin (STZ; dissolved in citrate buffer, $\mathrm{pH}$ 4.5) (17); Diabetic + insulin (D+I) group was i.p. treated with a single dose of $50 \mathrm{mg} / \mathrm{kg}$ STZ and subcutaneously (s.c.) with 2 IU insulin for 28 days (Levemir Flexpen) (40); Diabetic + A. tuncelianum extract (D+AT) group was i.p. treated with a single dose of 50 $\mathrm{mg} / \mathrm{kg} \mathrm{STZ}$ and orally with $250 \mathrm{mg} / \mathrm{kg}$ A. tuncelianum extract (dissolved in physiological saline solution, 1:1) for 28 days (38).

72 hours after STZ administration, the fasting blood glucose level of each rat was determined by glucometer (Bayer Contour TS, Germany). Rats with fasting blood glucose of $200 \mathrm{mg} / \mathrm{dl}$ were considered diabetic and included in the study (40).

The serum glycated hemoglobin $(\mathrm{HbAlc})$, insulin levels (Catalog No: E-EL-R2466) and the kidney and liver thiobarbituric acid reactive substances (TBARS), superoxide dismutase (SOD) (Catalog No: E-EL-R1424), and catalase (CAT) (Catalog No: E-EL-R2456) activities were determined by using ELISA kits (Elabscience, USA).

Upon completion of the study, all rats were sacrificed by sodium pentobarbital anesthesia $(30 \mathrm{mg} / \mathrm{kg})$. Blood samples were collected by intra-cardiac route from animals under sodium pentobarbital anesthesia and then centrifuged at $4000 \mathrm{~g}$ for $5 \mathrm{~min}$ to obtain serum samples. The kidney and liver tissues and serum samples were stored at $-20{ }^{\circ} \mathrm{C}$ until biochemical analysis. Before the biochemical analysis both tissue and serum samples were allowed to dissolve at room temperature. After the liver and kidney tissues were separated into pieces, one part of the tissue samples was homogenized (Wiggen Hauser, Germany) in cold phosphate-buffered saline (1:9) and centrifuged at $+4{ }^{0} \mathrm{C}, 10.000 \mathrm{~g}$ for $5 \mathrm{~min}$ to obtain a liver and kidney homogenate. 
Statistical analysis: A confidence level of 95\% (p < .05 ) and power of $75 \%$ were used. The calculation gave a sample size of 10. All statistical evaluations were made using the SPSS 18 package program. One way analysis of variance and Tukey's test were used to determine differences between the groups. All parameters were given as mean \pm SD. Significance was considered at $\mathrm{p}<0.05$.

\section{Results}

The blood glucose, serum HbA1c, and serum insulin levels of the rats in this study are shown in Table 1 . The kidney and liver TBARS levels, SOD and CAT activities of the rats in this study appear in Figure 1.

Our data showed that the blood glucose levels were significantly higher in the DC group compared to the control group $(\mathrm{p}<0.001)$. From the $7^{\text {th }}$ to the $28^{\text {th }}$ day in the D+AT group, the blood glucose levels were nonsignificantly lower at all measurements compared to the DC group. However, from the $7^{\text {th }}$ to the $28^{\text {th }}$ day in the D+I group, the blood glucose levels were significantly lower at all measurements compared to the DC group $(\mathrm{p}<0.05$, $\mathrm{p}<0.05, \mathrm{p}<0.01$, respectively).

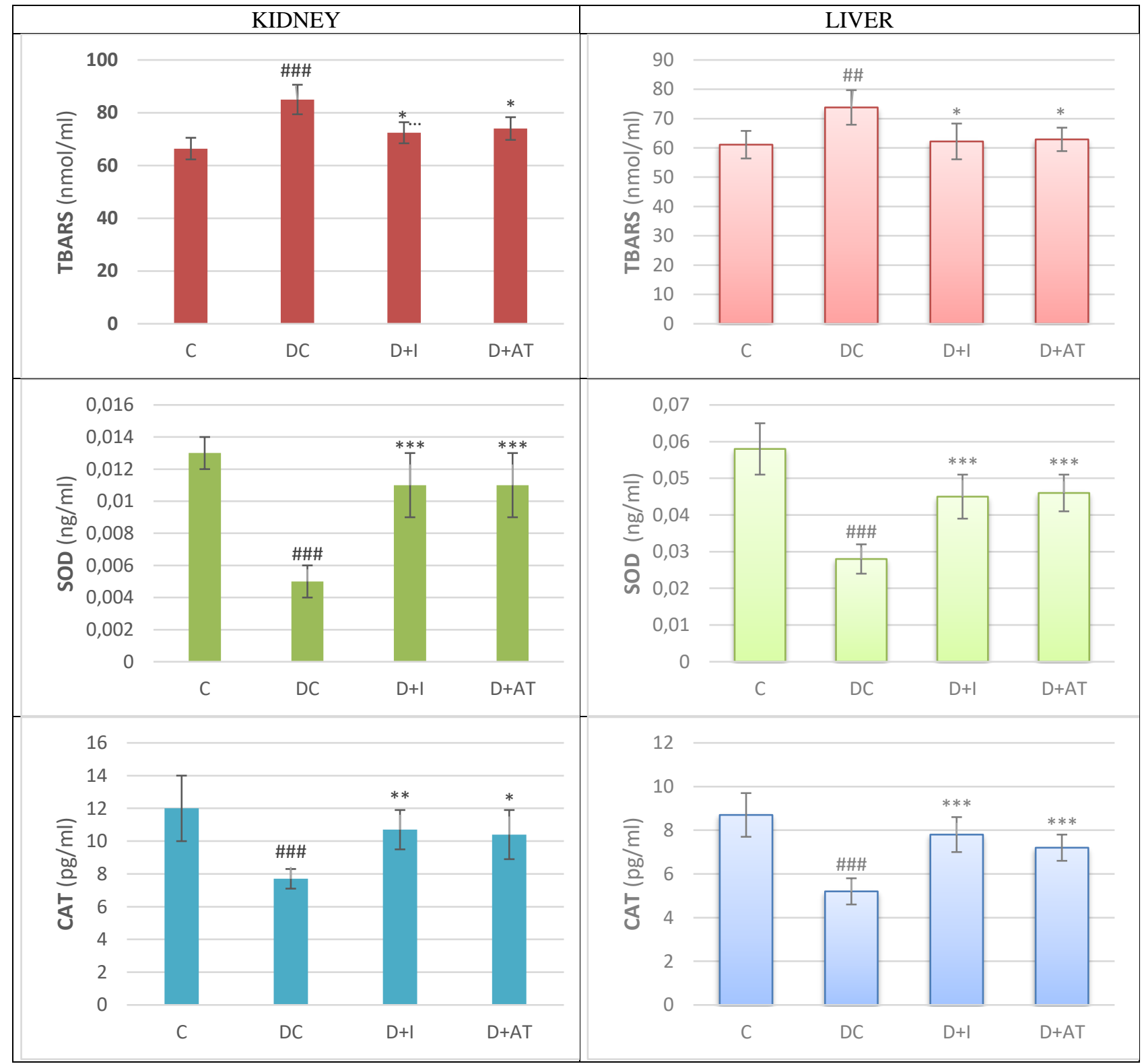

Figure 1. Effects of Allium tuncelianum extract on the kidney and liver TBARS, SOD and CAT levels in diabetic rats.

Şekil 1. Diyabetli ratlarda böbrek ve karaciğer TBARS, SOD ve CAT düzeyleri üzerine Allium tuncelianum ekstraktının etkileri.

C: Control group; DC: Diabetic control group; D+I: Diabetic+insulin group; D+AT: Diabetic+Allium tuncelianum group. The kidney and liver TBARS, SOD and CAT levels are provided as mean $\pm \mathrm{SD}$.

${ }^{\#} \mathrm{P}<0.05$ versus control group, ${ }^{\# \#} \mathrm{P}<0.01$ versus control group, ${ }^{\# \# \#} \mathrm{P}<0.001$ versus control group, ${ }^{*} \mathrm{p}<0.05$ versus diabetic control group, $* * \mathrm{p}<0.01$ versus diabetic control group, $* * * \mathrm{p}<0.001$ versus diabetic control group. 
Table 1. Effects of Allium tuncelianum extract on blood glucose, serum HbAlc and serum insulin levels in diabetic rats. Tablo 1. Diyabetli ratlarda kan glikoz, serum HbA1c ve serum insülin düzeyleri üzerine Allium tuncelianum ektraktının etkileri.

\begin{tabular}{|l|l|l|l|l|}
\hline Parameters & C & DC & D+I & D+AT \\
\hline Initial Glucose $(\mathrm{mg} / \mathrm{dl})$ & $84.0 \pm 3.0$ & $84.4 \pm 5.0$ & $87.5 \pm 5.2$ & $87.2 \pm 4.5$ \\
\hline Glucose on diabetes development $(\mathrm{mg} / \mathrm{dl})$ & $86.5 \pm 4.6$ & $399.0 \pm 9.8^{\# \#}$ & $393.9 \pm 14.1$ & $403.3 \pm 36.7$ \\
\hline Glucose on day 7 $(\mathrm{mg} / \mathrm{dl})$ & $81.7 \pm 3.4$ & $389.7 \pm 12.1^{\# \# \#}$ & $359.3 \pm 29.4^{*}$ & $379.8 \pm 12.2$ \\
\hline Glucose on day $14(\mathrm{mg} / \mathrm{dl})$ & $86.3 \pm 6.2$ & $392.7 \pm 15.7^{\# \#}$ & $358.3 \pm 27.9^{*}$ & $382.2 \pm 25.9$ \\
\hline Glucose on day 21 $(\mathrm{mg} / \mathrm{dl})$ & $83.7 \pm 4.5$ & $394.0 \pm 14.7^{\# \#}$ & $362.0 \pm 8.9^{* * *}$ & $383.8 \pm 14.9$ \\
\hline Glucose on day 28 (mg/dl) & $84.3 \pm 4.4$ & $401.7 \pm 10.7^{\# \#}$ & $347.6 \pm 43.0^{* *}$ & $389.2 \pm 10.6$ \\
\hline HbA1c $(\mathrm{ng} / \mathrm{ml})$ & $185.8 \pm 17.9$ & $355.1 \pm 22.6^{\# \# \#}$ & $285.0 \pm 15.4^{* * *}$ & $319.2 \pm 28.9^{*}$ \\
\hline Insulin $(\mathrm{ng} / \mathrm{ml})$ & $133.6 \pm 17.9$ & $90.8 \pm 13.3^{\# \#}$ & $150.7 \pm 15.2^{* * *}$ & $105.5 \pm 10.6$ \\
\hline
\end{tabular}

C: Control group; DC: Diabetic control group; D+I: Diabetic+insulin group; D+AT: Diabetic+Allium tuncelianum group. Blood glucose, serum $\mathrm{HbAlc}$ and serum insulin levels were given as mean $\pm \mathrm{SD}$.

${ }^{\#} \mathrm{P}<0.05$ versus control group, ${ }^{\# \#} \mathrm{P}<0.01$ versus control group, ${ }^{\# \# "} \mathrm{P}<0.001$ versus control group, ${ }^{*} \mathrm{p}<0.05$ versus diabetic control group, $* * \mathrm{p}<0.01$ versus diabetic control group, ${ }^{* * *} \mathrm{p}<0.001$ versus diabetic control group.

In the DC group, the serum HbA1c level significantly increased and the serum insulin level significantly decreased compared to the control group ( $\mathrm{p}<0.001)$. In the $\mathrm{D}+\mathrm{AT}$ and $\mathrm{D}+\mathrm{I}$ groups, the serum HbA1c levels significantly decreased compared to the DC group ( $\mathrm{p}<0.05, \mathrm{p}<0.001$ respectively). The serum insulin levels only significantly increased in the D+I group compared to the DC group $(\mathrm{p}<0.001)$. However, in the $\mathrm{D}+\mathrm{AT}$ group, the serum insulin level non-significantly increased compared to the DC group.

The kidney and liver TBARS levels significantly increased in the DC group compared to the control group ( $\mathrm{p}<0.001, \mathrm{p}<0.01$, respectively). The kidney and liver TBARS levels were significantly reduced in the D+I and $\mathrm{D}+\mathrm{AT}$ groups compared to the DC group $(\mathrm{p}<0.05)$. The kidney and liver SOD and CAT activities in the DC group were significantly reduced compared to the control group ( $\mathrm{p}<0.001)$. In the $\mathrm{D}+\mathrm{I}$ and $\mathrm{D}+\mathrm{AT}$ groups, the kidney and liver SOD activities were significantly enhanced compared to the DC group $(\mathrm{p}<0.001)$. In the $\mathrm{D}+\mathrm{I}$ and $\mathrm{D}+\mathrm{AT}$ groups, the kidney CAT activities were significantly enhanced compared to the DC group ( $\mathrm{p}<0.01, \mathrm{p}<0.05$, respectively). In the $\mathrm{D}+\mathrm{I}$ and $\mathrm{D}+\mathrm{AT}$ groups, the liver CAT activities were significantly enhanced compared to the DC group $(\mathrm{p}<0.001)$.

\section{Discussion and Conclusion}

The development of diabetes mellitus in rats in this study was induced by a single dose of $50 \mathrm{mg} / \mathrm{kg}$ i.p. streptozotocin injection. In the D+AT group, from day 7 through 28 the blood glucose levels non-significantly decreased compared to the DC group. In addition, the serum insulin levels in the D+AT group non-significantly increased compared to the DC group. The serum glycated hemoglobin levels significantly decreased in the D+AT group compared to the DC group. In this study, the decreased glycated hemoglobin levels revealed that the improvement effects in diabetic rats were developed by the treatment of $A$. tuncelianum extract at a dose of 250 $\mathrm{mg} / \mathrm{kg}$. However, the treatment dosage of $250 \mathrm{mg} / \mathrm{kg}$ of $A$. tuncelianum extract to reduce higher blood glucose levels in the D+AT group was likely low. For example, Thomson et al. (38) found a significant decrease in blood glucose levels and a significant increase in serum insulin levels in the treatment of diabetic rats with either 300 or $600 \mathrm{mg} / \mathrm{kg}$ dose of aged garlic.

Some studies revealed hypoglycemic effects of garlic extracts, but other studies have not. Shiju et al. (34) found a significant decrease in the glycated hemoglobin levels with the treatment of $500 \mathrm{mg} / \mathrm{kg}$ aged garlic (Allium sativum), but did not found a hypoglycemic effect in the diabetic rats. In contrast, Saravanan et al. (33) have suggested that $\mathrm{S}$-allylcysteine derived from garlic at a dose of $150 \mathrm{mg} / \mathrm{kg}$ normalizes blood glucose levels in the STZ diabetic rats. Similarly Rajani Kanth et al. (29) have revealed that garlic treatment at a dose of 250 and 500 $\mathrm{mg} / \mathrm{kg}$ significantly normalizes the blood glucose levels in the diabetic rats. In addition, Hassan et al. (15) have stated that garlic aqueous extract $(150 \mathrm{mg} / \mathrm{kg})$ in alloxan-induced diabetic rats significantly decrease the blood glucose levels (56\%). Nasiri et al. (25) have suggested that the blood glucose levels in diabetic rats were significantly decreased via garlic extract treatment $(2 \mathrm{~g} / \mathrm{kg} /$ day for 30 days). This can be attributed to the treatment doses of garlic in diabetic rats or the species of garlic.

The pathogenesis of diabetes mellitus has been implicated in oxidative stress via increased free radicals which are formed by glucose oxidation, glycosylated proteins, and then oxidative degradation of glycosylated proteins $(2,16,22)$. In addition, hyperglycemia has been revealed to promote oxidative stress by mitochondrial dysfunction and endoplasmic reticulum stress (32). Enhanced expressions of advanced glycation end products in the kidney and liver tissues were demonstrated in STZ 
diabetic rats (3), and enhanced advanced glycation end products have been indicated to have a role in the intracellular reactive oxygen species production, proinflammatory cytokines secretion, and collagen synthesis (20).

Several studies have indicated the development of oxidative stress in diabetic rats via increase in TBARS or lipid peroxide levels $(1,4,5)$ and decrease in antioxidant enzymes such as CAT, GPx activities (29) and SOD activity (9). In this study, it was found that the kidney and liver TBARS levels were significantly enhanced, while the kidney and liver SOD and CAT activities were significantly reduced in the DC rats compared to the control rats. This suggested that oxidative stress in the kidney and liver tissues occurred in rats with the STZinduced diabetes.

Oxidative stress causes impairment of membrane functions and disruption of the membranes (1). Decreased pancreatic islet cells, fibrosis of the pancreas, and liver degenerations due to oxidative stress have been indicated in diabetic rats (19). In this study, a decrease in the serum insulin levels of the diabetic rats may be associated with the occurrence of oxidative stress, increase in glycated hemoglobin levels and possible pancreatic $\beta$-cell disruption and pancreatic damage.

Garlic has been indicated to have antioxidant (37) and hypoglycemic activities and to attenuate $\beta$-cell destruction (19, 24). Similarly, Allium hookeri contributed to the regeneration of some $\beta$-cells and insulin secretion in the pancreas derangement caused by STZ (32). S-allyl cysteine sulfoxide as a garlic antioxidant compound (Allium sativum Linn) has been showed to ameliorate the diabetic rats induced by alloxan and to control lipid peroxidation (6). Similarly it has been shown that garlic administration significantly reduces ROS levels and significantly increases SOD, and CAT activities in hearts of diabetic rats (36). However, according to the author's knowledge, there have not been any studies on the hypoglycemic activity of $A$. tuncelianum extract in diabetic rats. In this study, $A$. tuncelianum extract had nonsignificant hypoglycemic effects. In addition, $A$. tuncelianum extract significantly increased the kidney and liver SOD and CAT activities in the DC rats, suggesting that A. tuncelianum extract has potent antioxidant activities.

In conclusion, the results of this study confirmed that A. tuncelianum extract had potent antioxidant activities in diabetic rats, and improvement effects by increasing insulin levels, decreasing glycated hemoglobin levels, and attenuating oxidative stress in the diabetes treatment in rats. Further studies are required for the assessment of higher dosages of A. tuncelianum extract on hypoglycemic activities in diabetic rats.

\section{References}

1. Abdultawab HS, Ayuob NN (2013): Can garlic oil ameliorate diabetes-induced oxidative stress in rat liver model? A correlated histological and biochemical study. Food Chem Toxicol, 59, 650-656.

2. Ahmed R (2005): The physiological and biochemical effects of diabetes on the balance between oxidative stress and antioxidant defense system. Med J Islam World Acad Sci, 15, 31-42.

3. Al-Qattan KK, Mansour MH, Thomson M, et al. (2016): Garlic decreases liver and kidney receptor for advanced glycation end products expression in experimental diabetes. Pathophysiology, 23, 135-145.

4. Anwar MM, Meki AR (2003): Oxidative stress in streptozotocin-induced diabetic rats: effects of garlic oil and melatonin. Comp Biochem Physiol A Mol Integr Physiol, 135, 539-547.

5. Aslan M, Orhan N, Deliorman Orhan D, et al. (2010): Hypoglycemic activity and antioxidant potential of some medicinal plants traditionally used in Turkey for diabetes. $\mathbf{J}$ Ethnopharmacol, 128, 384-389.

6. Augusti KT, Sheela CG (1996): Antiperoxide effect of $S$ allyl cysteine sulfoxide, an insulin secretagogue, in diabetic rats. Experientia, 52, 115-120.

7. Ayodhya S, Kusum S, Anjali S (2010): Hypoglycemic activity of different extracts of various herbal plants. Int $\mathbf{J}$ Ayurveda Res Pharm, 1, 212-224.

8. Badole SL, Ghule AE, Wagh NK (2013): Antidiabetic activity of Allium sativum. Bioactive food as dietary interventions for diabetes, http://dx.doi.org/10.1016/B9780-12-397153-1.00015-9.

9. Baluchnejadmojarad T, Kiasalari Z, Afshin-Majd S, et al. (2017): S-allyl cysteine ameliorates cognitive deficits in streptozotocin-diabetic rats via suppression of oxidative stress, inflammation, and acetylcholinesterase. Eur $\mathrm{J}$ Pharmacol, 794, 69-76.

10. Bombicino SS, Iglesias DE, Rukavina-Mikusic IA, et al. (2017): Hydrogen peroxide, nitric oxide and ATP are molecules involved in cardiac mitochondrial biogenesis in Diabetes. Free Radic Biol Med, 112, 267-276.

11. Chawla A, Chawla R, Jaggi S (2016): Microvascular and macrovascular complications in diabetes mellitus: Distinct or continuum? Indian J Endocrinol Metab, 20, 546-551.

12. Chung SS, Ho EC, Lam KS, et al. (2003): Contribution of polyol pathway to diabetes-induced oxidative stress. J Am Soc Nephrol, 14, S233-236.

13. Dorotea D, Kwon G, Lee JH, et al. (2018): A pan-NADPH oxidase inhibitor ameliorates kidney injury in type 1 diabetic rats. Pharmacology, 102, 180-189.

14. Gdula-Argasinska J, Pasko P, Sulkowska-Ziaja K, et al. (2017): Anti-inflammatory activities of garlic sprouts, a source of $\alpha$-linolenic acid and 5-hydroxy-l-tryptophan, in RAW 264.7 cells. Acta Biochim Pol, 64, 551-559.

15. Hassan F, Saadia M, Sher M, et al. (2018): Comparative Effects of Aqueous and Organic Solvent Extracts of Garlic on Glucose Level and Lipid Profile of Diabetic Rats. Pak J Zool, 50, 389-392.

16. Jakus V (2000): The role of free radicals, oxidative stress and antioxidants systems in diabetic vascular disease. Bratisl Lek Listy, 101, 541-551. 
17. Kandemir FM, Ozkaraca M, Küçükler S, et al. (2018): Preventive effects of hesperidin on diabetic nephropathy induced by streptozotocin via modulating TGF- $\beta 1$ and oxidative DNA damage. Toxin Rev, 37, 287-293.

18. Katsarou A, Gudbjörnsdottir S, Rawshani A, et al. (2017): Type 1 diabetes mellitus. Nat Rev Dis Primers, 3, 17016.

19. Kaur G, Padiya R, Adela R, et al. (2016): Garlic and resveratrol attenuate diabetic complications, loss of $\beta$-cells, pancreatic and hepatic oxidative stress in streptozotocininduced diabetic rats. Front Pharmacol, 7, 360.

20. Lohwasser C, Neureiter D, Popov Y, et al. (2009): Role of the receptor for advanced glycation end products in hepatic fibrosis. World J Gastroenterol, 15, 5789-5798.

21. Malik S, Suchal K, Khan SI, et al. (2017): Apigenin ameliorates streptozotocin-induced diabetic nephropathy in rats via MAPK-NF- $\kappa B-T N F$ - $\alpha$-and TGF- $\beta 1-M A P K-$ fibronectin pathways. Am J Physiol Renal Physiol, 313, F414-F422.

22. Maritim A, Sanders R, Watkins J (2003): Diabetes, oxidative stress, and antioxidants: a review. $\mathrm{J}$ Biochem $\mathrm{Mol}$ Toxicol, 17, 24-38.

23. Metiner K, Ozkan O, Ak S (2016): In vitro antibacterial and antifungal activity of ethanolic Allium tuncelianum extract. Global Veterinaria, 16, 26-30.

24. Morihara N, Hayama M, Fuji H (2011): Aged garlic extract scavenges superoxide radicals. Plant Foods Hum Nutr, 66, 17-21.

25. Nasiri A, Ziamajidi N, Abbasalipourkabir R, et al. (2017): Beneficial effect of aqueous garlic extract on inflammation and oxidative stress status in the kidneys of type 1 diabetic rats. Indian J Clin Biochem, 32, 329-336.

26. Niedowicz DM, Daleke DL (2005): The role of oxidative stress in diabetic complications. Cell Biochem Biophys, $\mathbf{4 3}$, 289-330.

27. Ozkan O, Gül S, Kart A, et al. (2013): In vitro antimutagenicity of Allium tuncelianum ethanol extract against induction of chromosome aberration by mutagenic agent mitomycine C. Kafkas Univ Vet Fak Derg, 19, 259262.

28. Patel DK, Prasad SK, Kumar R, et al. (2012). An overview on antidiabetic medicinal plants having insulin mimetic property. Asian Pac J Trop Biomed, 2, 320-330.

29. Rajani Kanth V, Uma Maheswara Reddy P, Raju TN (2008): Attenuation of streptozotocin-induced oxidative stress in hepatic and intestinal tissues of Wistar rat by methanolic-garlic extract. Acta Diabetol, 45, 243-251.

30. Rodriguez V, Plavnik L, Tolosa de Talamoni N (2018): Naringin attenuates liver damage in streptozotocin-induced diabetic rats. Biomed Pharmacother, 105, 95-102.

31. Roe ND, Thomas DP, Ren J (2011): Inhibition of NADPH oxidase alleviates experimental diabetes-induced myocardial contractile dysfunction. Diabetes Obes Metab, 13, 465-473.
32. Roh SS, Kwon OJ, Yang JH, et al. (2016): Allium hookeri root protects oxidative stress-induced inflammatory responses and $\beta$-cell damage in pancreas of streptozotocininduced diabetic rats. BMC Complement Altern Med, 16, 63.

33. Saravanan G, Ponmurugan P (2010): Beneficial effect of S-allylcysteine (SAC) on blood glucose and pancreatic antioxidant system in streptozotocin diabetic rats. Plant Foods Hum Nutr, 65, 374-378.

34. Shiju TM, Rajesh NG, Viswanathan P (2013): Renoprotective effect of aged garlic extract in streptozotocin-induced diabetic rats. Indian J Pharmacol, 45, 18-23.

35. Sivaraman K, Senthilkumar GP, Sankar P, et al. (2013): Attenuation of oxidative stress, inflammation and insulin resistance by Allium sativum in fructose-fed male rats. $\mathbf{J}$ Clin Diagn Res, 7, 1860-1862.

36. Sultana MR, Bagul PK, Katare PB, et al. (2016). Garlic activates SIRT-3 to prevent cardiac oxidative stress and mitochondrial dysfunction in diabetes. Life Sci, 164, 42-51.

37. Takım K (2015): Tunceli Dă̆ Sarımsă̆g'nın (Allium tuncelianum) in vitro antioksidan kapasitesinin ölçülmesi, ratlarda antioksidan enzim aktiviteleri üzerine etkisi ve antikanser özelliğinin belirlenmesi. T.C. İnönü Üniversitesi Fen Bilimleri Enstitüsü, Doktora Tezi.

38. Thomson M, Al-Qattan KK, Divya JS, et al. (2016): Antidiabetic and anti-oxidant potential of aged garlic extract $(A G E)$ in streptozotocin-induced diabetic rats. BMC Complement Altern Med, 16, 17.

39. Tomita T (2017): Apoptosis of pancreatic $\beta$-cells in type 1 diabetes. Bosn J Basic Med Sci, 17, 183-193.

40. Uslu H, Atila Uslu G, Özen H, et al. (2018): Effects of different doses of Prunus laurocerasus L. leaf extract on oxidative stress, hyperglycemia and hyperlipidaemia induced by type I diabetes. IJTK, 17, 430-436.

41. Varga ZV, Giricz Z, Liaudet L, et al. (2015): Interplay of oxidative, nitrosative/nitrative stress, inflammation, cell death and autophagy in diabetic cardiomyopathy. Biochim Biophys Acta, 1852, 232-42.

42. Zahid Ashraf M, Hussain ME, Fahim M (2005): Antiatherosclerotic effects of dietary supplementations of garlic and turmeric: Restoration of endothelial function in rats. Life Sci, 77, 837-857.

Geliş tarihi: 04.06.2018 / Kabul tarihi: 11.03.2019

Address for correspondence:

Prof. Dr. Ali BILLGíL

Ankara University, Faculty of Veterinary Medicine, Department of Pharmacology and Toxicology, 06110,

Dışkapı, Ankara, Turkey

e-mail:abilgili61@gmail.com 